\title{
Civil Engineering Quantities
}


By the same author

Building Economics

Building Maintenance

Building Quantities Explained

Building Technology

Civil Engineering Specification

Municipal Engineering Practice

Outdoor Recreation and the Urban Environment

Planned Expansion of Country Towns 


\section{Civil Engineering Quantities}

\section{Ivor H. Seeley}

B.Sc., M.A., Ph.D., C. Eng., F.R.I.C.S.,

F.I.Mun.E., F.I.Q.S., M.I.O.B.

Chartered Quantity Surveyor and Chartered Engineer,

Head of the Department of Surveying and

Dean of the School of Environmental Studies,

Trent Polytechnic, Nottingham

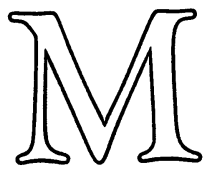


(C) Ivor H. Seeley $1965,1971,1977$

Softcover reprint of the hardcover 3rd edition 1977

All rights reserved. No part of this publication may be reproduced or transmitted, in any form or by any means, without permission.

First edition 1965

Reprinted 1968

SI edition 1971

Reprinted 1972, 1974

Printed-case edition 1975

Reprinted 1976

Third edition 1977

Published by

THE MACMILLAN PRESS LTD

London and Basingstoke

Associated companies in Delhi Dublin

Hong Kong Johannesburg Lagos Melbourne

New York Singapore and Tokyo

ISBN 978-1-349-03528-1

DOI 10.1007/978-1-349-03526-7

Typeset in 10/12 IBM Press Roman by

Santype International Limited,

Salisbury, Wiltshire

This book is sold subject to the standard conditions of the Net Book Agreement. 


\section{Contents}

$\begin{array}{ll}\text { Preface } & \text { ix }\end{array}$

Acknowledgements $\quad$ x

Subjects Illustrated by Examples $\quad$ xii

1. Scope of Civil Engineering Works and Method of Measurement 1

Introduction - Development of Civil Engineering Codes of Measurement - Scope of Civil Engineering Works - Comparison of Civil Engineering and Building Methods of Measurement

2. Civil Engineering Contracts and Contract Documents

The Nature and Form of Contracts - Enforcement of Contracts Validity of Contracts - Remedies for Breach of Contract - Civil Engineering Contracts - Types of Contract Encountered in Civil Engineering Works - Contract Documents, Including Reference to Appropriate Clauses in ICE Conditions of Contract

3. General Arrangement and Contents of Civil Engineering Bills of Quantities

Introduction - Definitions - General Principles - Application of the Work Classification - Coding and Numbering of Items Preparation of Bills of Quantities: List of Principal Quantities, Preamble, Prime Cost Items, Provisional Sums, Quantities

4. Method-related Charges and Pricing and Measurement of Civil Engineering Work

Method-related Charges: Underlying Philosophy, Objectives, Division into Time-related and Fixed Charges, Application, Advantages and Disadvantages - Class A: General Items - Effect of CESMM on Pricing - Measurement Processes 
5. Measurement of Site Investigation, Geotechnical Processes,

Demolition and Site Clearance

General Principles - Typical Site Investigation Bill - Worked

Example of Measurement of Site Clearance

6. Measurement of Earthworks

General Principles - Worked Example of Measurement of

Excavation and Filling

7. Measurement of Concrete

General Principles - Worked Examples of Measurement of Mass

Concrete Retaining Wall, Reinforced Concrete Pumping Station and

Prestressed Concrete Beams

8. Measurement of Brickwork, Blockwork, Masonry, Painting and Waterproofing

General Principles - Worked Examples of Measurement of Tall Brick Chimney Shaft, Deep Brick Manhole, Stone-faced Sea Wall and Pumphouse

9. Measurement of Piles

General Principles - Worked Examples of Measurement of Concrete and Timber Piles and Steel Sheet Piling

10. Measurement of Timber and Associated Work

General Principles - Worked Example of Measurement of Timber Jetty

11. Measurement of Metalwork

General Principles - Worked Example of Measurement of Steel Framed Gantry

12. Measurement of Roads and Pavings

General Principles - Worked Example of Measurement of Estate Road

13. Measurement of Pipework

General Principles - Worked Examples of Measurement of Sewer and Water Main 
14. Measurement of Tunnels

General Principles - Worked Example of Measurement of Cast Iron Tunnel Lining

15. Measurement of Rail Track

General Principles - Worked Example of Measurement of Railway Track

16. Bill Preparation Processes

Working-up Generally - Billing Direct - Squaring the Dimensions Abstracting - Billing - Recent Developments in Bill Preparation 'Cut and Shuffle' - Use of Computers - Typical Abstract and Bill

Appendix I - Abbreviations

Appendix II - Mensuration Formulae

Index 


\section{Preface to Third Edition}

This book has been substantially rewritten to take account of changes in the Conditions of Contract for use in connection with Works of Civil Engineering Construction and the entirely new philosophy and approach introduced by the 1976 Civil Engineering Standard Method of Measurement (CESMM). Steps have been taken to extend the usefulness of the book and yet, at the same time, make it more concise.

The new CESMM seeks to secure a more comprehensive, uniform and rationalised approach to measurement with its standardised terminology and three levels of description. The introduction, for the first time, of methodrelated charges deserves particular attention, and their use on a wide scale should reduce Contractors' cash flow problems and assist considerably with the pricing of variations. Not all costs are proportional to the quantities of permanent work on the majority of civil engineering contracts, and the use of method-related charges assists in the identification and assessment of such costs.

This edition examines the new CESMM in detail and applies the Method to a wide range of constructional work by means of worked examples. The worked examples contain suitable drawings and the hand-written dimensions are accompanied by extensive explanatory notes describing the approach to measurement and the application of the general principles, work classifications and accompanying notes contained in the CESMM. The CESMM coding has been included in the worked examples for identification purposes.

The provisions in the ICE Conditions of Contract appertaining to measurement and financial aspects of contracts are examined in some detail together with the more significant consequences.

Finally, the various bill preparation processes are described and illustrated.

It is hoped that this new edition will serve the needs of practising civil engineers and quantity surveyors and students of these disciplines, in the measurement of this class of work, even more effectively than the previous editions. 


\section{Acknowledgements}

The author expresses his thanks to The Institution of Civil Engineers for kind permission to quote from the Civil Engineering Standard Method of Measurement and the General Conditions of Contract for use in connection with Works of Civil Engineering Construction.

Some of the worked examples follow a similar pattern to those which the author prepared some years ago for the Ellis School of Architecture, Surveying and Building, London and Worcester.

Grateful thanks are also due to the publishers for abundant help and consideration during the production of the book. 


\section{Abbreviations}

Will be found listed in Appendix I. 


\section{Subjects Illustrated by Examples}

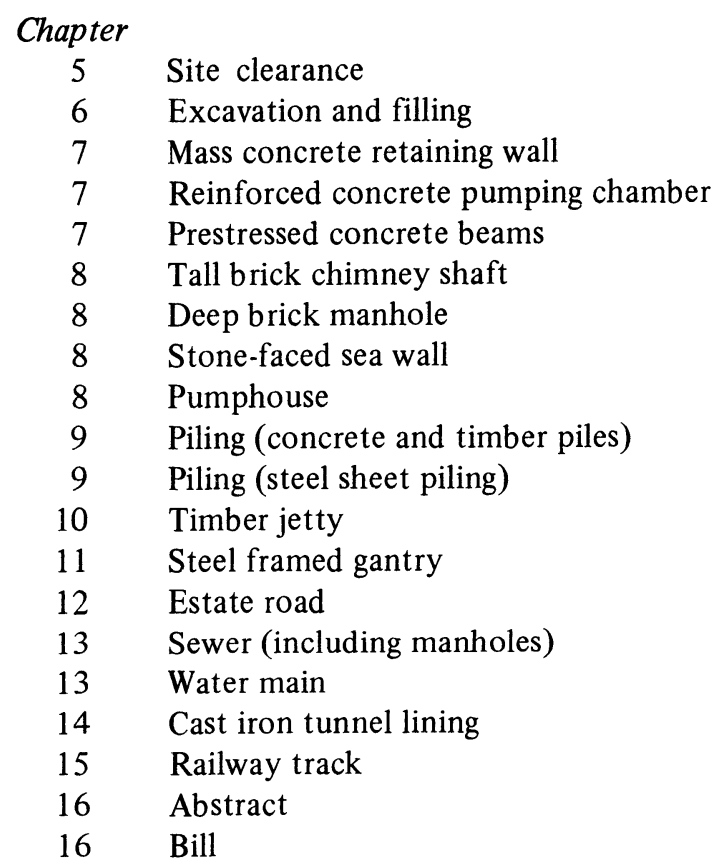

$\begin{array}{rcr}\text { Example } & \text { Drawing } & \text { Page } \\ \text { I } & 1 & 71 \\ \text { II } & 2 & 79 \\ \text { III } & 3 & 93 \\ \text { IV } & 4 \text { and } 5 & 97 \\ \text { V } & 6 & 105 \\ \text { VI } & 7 & 110 \\ \text { VII } & 8 \text { and } 9 & 116 \\ \text { VIII } & 10 & 127 \\ \text { IX } & 11 & 135 \\ \text { X } & 12 \text { and } 13 & 146 \\ \text { XI } & 13 & 153 \\ \text { XII } & 14 & 156 \\ \text { XIII } & 15 \text { and } 16 & 165 \\ \text { XIV } & 17 \text { and } 18 & 172 \\ \text { XV } & 19 \text { and } 20 & 187 \\ \text { XVI } & 22 & 198 \\ \text { XVII } & 21 & 205 \\ \text { XVIII } & - & 208 \\ \text { XIX } & - & 220 \\ \text { XX } & - & 223\end{array}$

